\title{
Effect of severe thermal treatment on spruce and beech wood lignins
}

\author{
Patrick RousseT ${ }^{1 *}$, Catherine LAPIERRE ${ }^{2},{\text { Brigitte } \text { POLLET }^{2} \text {, Waldir QUIRINO }}^{3}$, Patrick PERRE $^{4}$ \\ ${ }^{1}$ UPR42 - Biomass Energy Unit, CIRAD/LPF-SFB, Brasilia DF, 708 18-900, Brazil \\ ${ }^{2}$ UMR - Chimie Biologique AgroParisTech/INRA, AgroParisTech Centre de Grignon, 78850 Thiverval-Grignon, France \\ ${ }^{3}$ Biomass Energy Research Unit, LPF-SFB, Brasilia DF, 708 18-900, Brazil \\ ${ }^{4}$ LERMAB, UMR1093, INRA, ENGREF, 14 rue Girardet, 54042 Nancy cedex, France
}

Keywords:

lignin /

thermal treatment /

thioacidolysis /

spruce /

beech

(Received 23 April 2008; accepted 4 October 2008)

\author{
Mots-clés : \\ lignine / \\ traitement thermique / \\ thioacidolyse / \\ épicéa / \\ hêtre
}

\begin{abstract}
- The structure, proportion and mode of assembly of lignin, celluloses and hemicelluloses have marked effects on the reaction mechanisms during thermal treatment and therefore have a strong influence on the quality of the final product. The effect of treatment conditions, including severe conditions (up to $553 \mathrm{~K}$ ) and treatment duration (up to $8 \mathrm{~h}$ ) on the structure of native spruce and beech lignins was studied.

- Lignin content was determined by the Klason method and lignin structure was evaluated by thioacidolysis.

- The results highlighted the strong reactivity of the native spruce and beech lignins towards severe heat treatments. The distinct susceptibility of syringyl (S) and guaiacyl $(\mathrm{G})$ units towards thermal treatment is confirmed by comparing the data for beech and spruce samples. The most severe treatment of spruce wood $\left(280{ }^{\circ} \mathrm{C}\right)$ induced a dramatic enrichment in lignin content together with the almost complete disappearance of $\mathrm{G}$ lignin units, whereas a more moderate treatment substantially changed lignin structure by degradation reactions that affect the $p$-hydroxyphenyl $(\mathrm{H})$ and $\mathrm{G}$ lignin units similarly.

- Thioacidolysis revealed that the thermal treatment induces the appearance of vinyl ether structures in spruce lignins. The decreased yield of the $\mathrm{G}$ and $\mathrm{S}$ thioacidolysis monomers reflects the progressive disappearance of $\mathrm{G}$ and $\mathrm{S}$ lignin units only involved in $\beta-\mathrm{O}-4$ bonds and the formation of condensed linkages in proportions related to treatment severity. In severe conditions, $\beta$-O-4 linked $\mathrm{S}$ units are more degraded than their $\mathrm{G}$ homologues.
\end{abstract}

Résumé - Effet d'un traitement thermique sévère sur les lignines du bois d'épicéa et de hêtre. - La structure, la proportion et le mode de montage de la lignine, des celluloses et des hémicelluloses ont eu des effets marqués sur les mécanismes de la réaction au cours du traitement thermique et, par conséquent, ont eu une forte influence sur la qualité du produit final. L'effet des conditions de traitement, y compris des conditions sévères (jusqu'à $553 \mathrm{~K}$ ) et la durée du traitement (jusqu'à $8 \mathrm{~h}$ ) sur la structure de lignines de l'épicéa et du hêtre ont été étudiés.

- La teneur en lignine a été déterminée par la méthode Klason et la structure de la lignine a été évaluée par thioacidolyse.

- Les résultats ont mis en évidence la forte réactivité des lignines de l'épicéa et du hêtre vis-àvis des traitements thermiques sévères. La sensibilité des différentes unités syringyl (S) et guaiacyl (G) vis-à-vis du traitement thermique est confirmée par comparaison des données obtenues avec les échantillons du hêtre et de l'épicéa. Le traitement le plus sévère $\left(280^{\circ} \mathrm{C}\right)$ du bois d'épicéa a induit un enrichissement spectaculaire en lignine ainsi que la quasi-disparition des unités de la lignine $\mathrm{G}$, alors qu'un traitement plus modéré a sensiblement modifié la structure de la lignine par des réactions de dégradation qui affectent les p-hydroxyphényl $(\mathrm{H})$ et les unités de lignine $\mathrm{G}$.

- La thioacidolyse a révélé que le traitement thermique induit l'apparition de structures de vinyl éthers dans la lignine de l'épicéa. La diminution de production de la $\mathrm{G}$ et $\mathrm{S}$ thioacidolyses monomères reflète la disparition progressive des unités de lignine $\mathrm{G}$ et $\mathrm{S}$ impliquées seulement dans des liaisons $\beta-\mathrm{O}-4$ et la formation de linkages de condensation en proportions de la sévérité du traitement. Dans des conditions difficiles, les unités $\mathrm{S}$ liées $\beta$-O-4 sont plus dégradées que leurs homologues $\mathrm{G}$.

\footnotetext{
* Corresponding author: Patrick.rousset@ cirad.fr
} 


\section{INTRODUCTION}

The effects of high temperature treatments $\left(200-250{ }^{\circ} \mathrm{C}\right)$ on wood have been studied for over fifty years (Scheffer and Eslyn, 1961; Stamm, 1946). While the beneficial effects of thermal treatment on wood properties were brought to light several centuries ago, industrial exploitation of this phenomenon is quite recent and it is only in the last 20 years that this question has been scientifically investigated (Bourgois et al., 1989; Branca and Di Blasi, 2003; Tjeerdsma et al., 1998). Recent studies have highlighted the technological importance of controlling the heating rate as well as the final temperature and its duration (Kocaefe et al., 2006; Rapp, 2001). The interaction between these three parameters results in more or less complete reactions of vaporization, decomposition and condensation involving the various wood components (Funaoka et al., 1990; Rousset et al., 2006). The immediate effects are changes in the physico-chemical properties of the treated wood (Arias et al., 2008; Mouras et al., 2002; Nuopponen 2005; Windeisen et al., 2007). Higher temperature levels, generally up to $250{ }^{\circ} \mathrm{C}$, have a greater effect on wood durability, but may be detrimental to mechanical properties such as resilience, the ability of the material to withstand impact (Borrega and Kärenlampi1, 2007; Yildiz et al., 2006).

Wood is a bio-composite, mainly formed by the combination of three cell wall polymers (cellulose, hemicelluloses and lignins). The structure, proportion and mode of assembly of these polymers have marked effects on the reaction mechanisms during thermal treatment and therefore have a strong influence on the quality of the final product (Boonstra et al., 2007; Kotilainen, 2000).

Lignins are probably the most difficult biopolymers to characterize structurally, but recent advances in analytical chemistry and spectroscopy have substantially improved our knowledge of this natural resource (Chakar and Ragauskas, 2004). However, the reactivity of lignins to thermal treatments has been less studied than that of cellulose or hemicelluloses, and is therefore still poorly understood (Baumberger et al., 2002; Blazek et al., 2001; Vallet et al., 2001; Windeisen and Wegener, 2008). Lignins are phenolic cell wall polymers with a variable and complex structure. The native lignins of conifers are essentially constituted of guaiacyl $(\mathrm{G})$ units together with a low proportion of $p$-hydroxyphenyl $(\mathrm{H})$ units (except in compression wood rich in $\mathrm{H}$ units). Along with the $\mathrm{G}$ units and traces of $\mathrm{H}$ units, the lignins of deciduous trees are constituted of syringyl $(\mathrm{S})$ units. The main inter-unit bond of native lignins is the so-called $\beta \mathrm{O} 4$ linkage. The arylglycerol- $\beta$-ether structures outlined in Figure 1 are the main targets of the industrial delignification processes. Lignin units can also be involved in resistant inter-unit linkages (referred to as condensed linkages) such as 5-5 biphenyl linkages. The proportion of resistant bonds in native lignins increases with the frequency of $\mathrm{G}$ and $\mathrm{H}$ units whereas $\mathrm{S}$ units are mostly involved in $\beta-\mathrm{O}-4$ linkages.

In this context the present study aims to at the compare the effect of severe thermal treatments on the structure and content of lignins in Norway spruce and beech wood, using high temperatures, long durations and an inert atmosphere. The re-

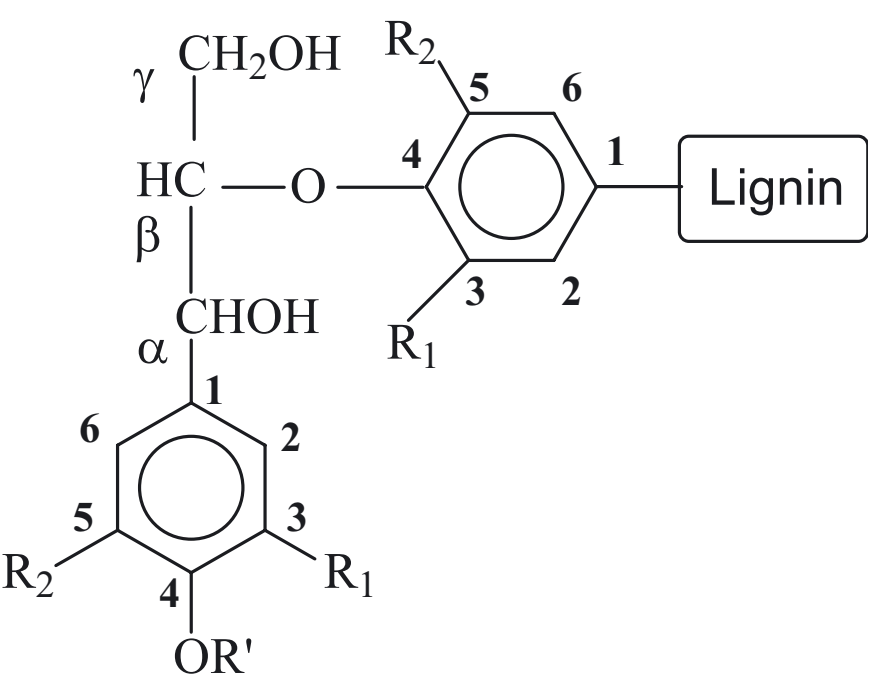

Figure 1. Structure of the lignin phenylpropane $\mathrm{C}_{6} \mathrm{C}_{3}$ units $\left(\mathrm{R}_{1}=\mathrm{R}_{2}=\mathrm{H}\right.$ in $p$-hydroxyphenyl units; $\mathrm{R}_{1}=\mathrm{OMe}$ and $\mathrm{R}_{2}=\mathrm{H}$ in guaiacyl units; $\mathrm{R}_{1}=\mathrm{R}_{2}=\mathrm{OMe}$ in syringyl units) and of their most common bonding mode (referred to as the $\beta-\mathrm{O}-4$ bond) in native lignins. The structures are outlined with the conventional carbon numbering ( $\mathrm{R}^{\prime}=\mathrm{H}$ or $\mathrm{C}$ of another $\mathrm{C}_{6} \mathrm{C}_{3}$ unit).

sults should provide indications for improving the control of the heating process and hence improve the quality of torrefied wood.

\section{MATERIALS AND METHODS}

\subsection{Materials}

Beech (Fagus sylvatica L.) and spruce (Picea abies) logs were sawn into $50 \mathrm{~mm}$-thick and quartersawn boards. They were then dried to an average humidity of ca. $13 \%$. For the comparative studies on the effects of temperature level and treatment duration, the wood samples were taken from a single longitudinal section in order to limit variation due to the natural variability of wood and thus guarantee a good reproducibility of the results (Fig. 2a). Sample dimensions were $20 \mathrm{~mm} \times 12 \mathrm{~mm} \times 3 \mathrm{~mm}(\mathrm{~L}, \mathrm{R}, \mathrm{T})$ before treatment, thus allow a good homogeneity on the treatment.

\subsection{Thermal treatment}

The wood samples were divided into 6 sets and subjected to three temperature levels and three treatment durations (Tab. I), in an inert atmosphere $\left(\mathrm{N}_{2}\right)$. The experimental setup is composed of an oven with an electrical resistance with regulated temperature, an $\mathrm{O}_{2}$ and $\mathrm{CO}_{2} / \mathrm{CO}$ analyser and an analogical to digital converter (ADC) linked to a computer in order to control the operating conditions (Fig. 2b). A fan forces the air to circulate in the chamber in a closed loop. The nitrogen inlet was controlled such that the oxygen level remained below $3 \%$ to better control of the main wood components reactivity involving in the chemical reactions (Bilbao et al., 1997).

It is well-known that the properties of treated wood change significantly depending on the temperature level and the process duration. 


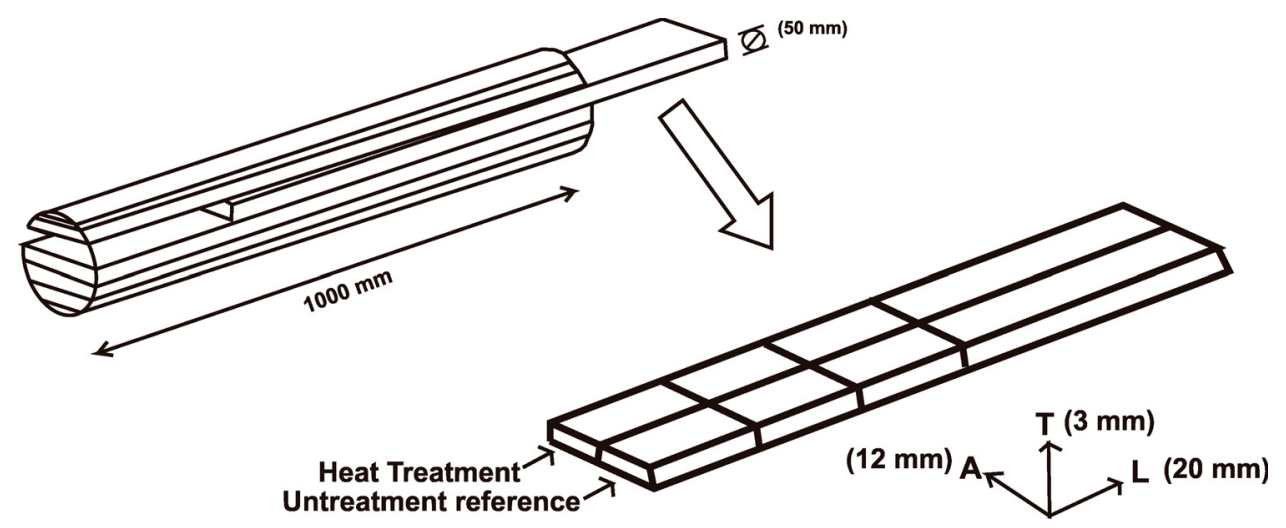

(a)

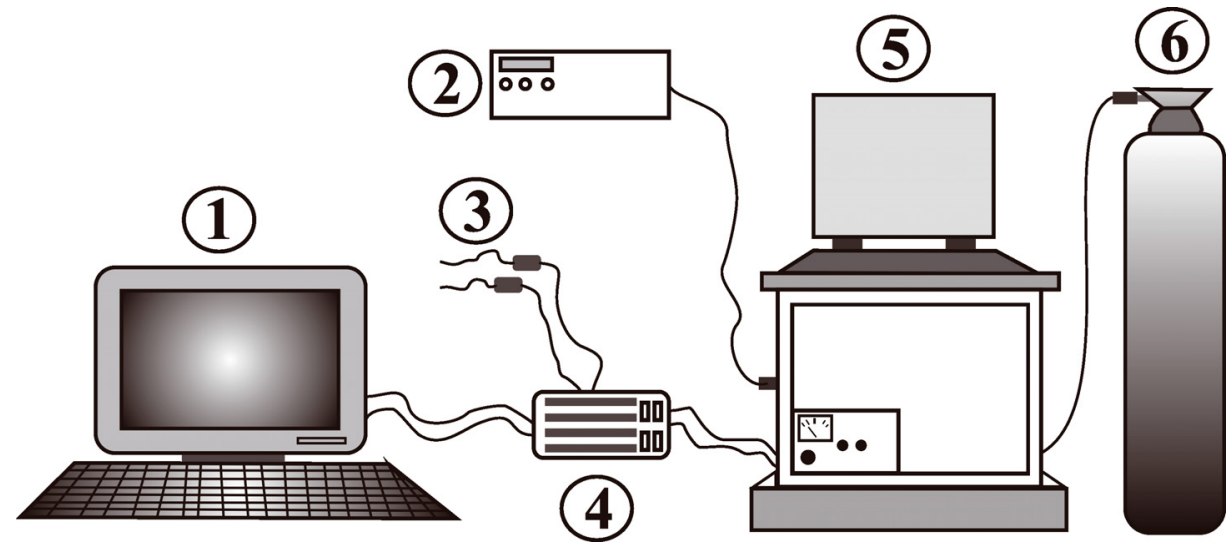

(b)

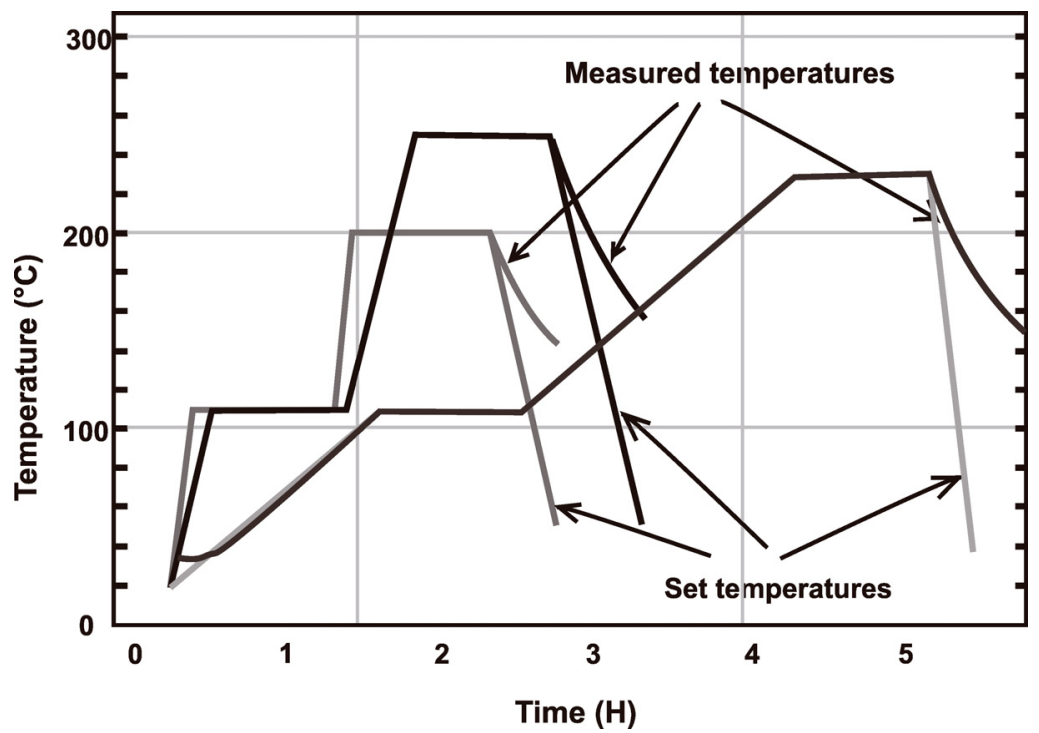

(c)

Figure 2. (a) Orientation and position of sampling from a board. (b) The experimental device used for thermal treatment: $1-$ monitoring; 2 - $\mathrm{O}_{2}$ analyser; 3 - probes; 4 - data capture; 5 - reactor; 6 - nitrogen. (c) Temperature evolution in the chamber during a typical heat treatment (set and measured temperature). 
Table I. Thermal treatments of spruce and beech wood samples.

\begin{tabular}{|c|c|c|c|}
\hline \multicolumn{2}{|r|}{ Spruce } & \multicolumn{2}{|r|}{ Beech } \\
\hline No. & Treatment & No. & Treatment \\
\hline P1 & Control sample & P8 & Control sample \\
\hline $\mathrm{P} 2$ & $220^{\circ} \mathrm{C}$ and $1 \mathrm{~h}$ & P9 & $220^{\circ} \mathrm{C}$ and $1 \mathrm{~h}$ \\
\hline P3 & $250^{\circ} \mathrm{C}$ and $1 \mathrm{~h}$ & P10 & $250^{\circ} \mathrm{C}$ and $1 \mathrm{~h}$ \\
\hline P4 & $280^{\circ} \mathrm{C}$ and $1 \mathrm{~h}$ & P11 & $280^{\circ} \mathrm{C}$ and $1 \mathrm{~h}$ \\
\hline P5 & $220^{\circ} \mathrm{C}$ and $8 \mathrm{~h}$ & P12 & $220^{\circ} \mathrm{C}$ and $8 \mathrm{~h}$ \\
\hline P6 & $250^{\circ} \mathrm{C}$ and $8 \mathrm{~h}$ & P13 & $250^{\circ} \mathrm{C}$ and $8 \mathrm{~h}$ \\
\hline P7 & $280^{\circ} \mathrm{C}$ and $8 \mathrm{~h}$ & P14 & $280^{\circ} \mathrm{C}$ and $8 \mathrm{~h}$ \\
\hline
\end{tabular}

Therefore, several precautions were taken to ensure good control of the sample temperature, the treatment duration and the uniformity within the section. The first step for each treatment was to dry the samples for $30 \mathrm{~min}$ at $110{ }^{\circ} \mathrm{C}$ so as to avoid the effect of moisture, which delays the temperature increase of the sample due to evaporation. This was followed by a high heating rate of $5{ }^{\circ} \mathrm{C} / \mathrm{min}$ in all treatments in order to minimize chemical modifications taking place outside the treatment period .

Finally, we wanted the temperature history of the wood sample to be very close to that of the set temperature acting on the gas flow. This was ensured by a high heat transfer coefficient at the interface (using a copper sample of similar geometry, the average heat transfer coefficient was found to be $28 \mathrm{~W} / \mathrm{m}^{2} /{ }^{\circ} \mathrm{C}$ ) and by choosing a small sample thickness to reduce the time constant related to thermal diffusion in wood. This time constant $\tau$ reads as

$$
\tau=\frac{t^{2} \rho C_{p}}{\lambda} \quad[s] .
$$

In Equation (1), $\mathrm{t}$ is the half-thickness of the sample ( $\mathrm{m}), \rho$ the wood density $\left(\mathrm{kg} \cdot \mathrm{m}^{3}\right), C_{p}$ the specific heat capacity of wood $\left(\mathrm{J} \cdot \mathrm{kg}^{-1} \cdot \mathrm{K}^{-1}\right)$ and $\lambda$ the thermal conductivity of wood $\left(\mathrm{J} \cdot \mathrm{s}^{-1} \cdot \mathrm{m}^{-1} \cdot \mathrm{K}^{-1}\right)$. Using usual values for wood $\left(\rho=500 \mathrm{~kg} \cdot \mathrm{m}^{3}, C_{p}=1250 \mathrm{~J} \cdot \mathrm{kg}^{-1} \cdot \mathrm{K}^{-1}\right.$ and $\lambda=$ $0.15 \mathrm{~J} \cdot \mathrm{s}^{1} \cdot \mathrm{m}^{-1} \cdot \mathrm{K}^{-1}$ ) and with a total thickness of $3 \mathrm{~mm}$, the time constant $\tau$ is less than $10 \mathrm{~s}$. This value is very small relative to the treatment duration, so ensuring a uniform treatment throughout the section.

\subsection{Lignin analyses}

The thermally-treated and the corresponding control samples were ground $(<0.5 \mathrm{~mm})$ and the milled samples were extracted (Soxhlet extractor) with ethanol/toluene $(1 / 2, \mathrm{v} / \mathrm{v})$, ethanol, then water in order to eliminate all the soluble components that could interfere with the gravimetric lignin determinations. The weight loss associated with this extraction method was found to be in the 5-10\% range for all samples. All the following analytical characterizations were carried out on the extractive-free milled samples.

The sample lignin content was determined using the Klason method. This gravimetric measurement was carried out for each sample as an independent duplicate analysis. Each Klason lignin measurement was performed from $300 \mathrm{mg}$ of extract-free sample and according to the standard method described in (Dence, 1992). The possible presence of an acido-soluble lignin fraction in the sulphuric supernatant was examined using UV spectrometry at $205 \mathrm{~nm}$ (Dence, 1992).

To evaluate the effect of thermal treatment on lignin structure, we used thioacidolysis, which requires only a few milligrams of wood
(Rolando et al., 1992). The principle of thioacidolysis and the significance of the lignin-derived thioacidolysis monomers are as follows. During thioacidolysis, the H, G and S lignin units only involved in arylglycerol $\beta$ ether structures give rise to thioethylated $\mathrm{H}$, $\mathrm{G}$ and $\mathrm{S} \mathrm{C}_{6} \mathrm{C}_{3}$ monomers (monomers A pathway 1, Fig. 3). However, a small proportion of these parent lignin units (about 5 to $10 \%$ according to model compound studies) is degraded into thioethylated $\mathrm{C}_{6} \mathrm{C}_{2}$ monomers and through a minor reaction pathway (monomers $\mathrm{B}$, pathway 2, Fig. 3). While B monomers are recovered in low proportions from native lignins, they are the main products released from vinyl ether structures present in degraded lignins (pathway 3, Fig. 3). These $\beta-O-4$ linked vinyl ethers are formed when the $\gamma$ hydroxymethyl group of arylglycerol- $\beta$-ether structures is lost as formaldehyde and by a reverse aldol condensation reaction. Such reactions have been shown to occur during kraft pulping (Gellerstedt et al., 1984; Rolando et al., 1992) and also during the thermal treatment of pine wood (Vallet et al., 2001). In this study, the proportion of lignin units only involved in $\beta-\mathrm{O}-4$ bonds was evaluated from the yield of the main monomers $(\mathrm{A}+\mathrm{B})$, whether these monomers originate from arylglycerol- $\beta$ ethers or from vinyl ethers (these latter structures are not found in native lignins). If the relative proportion of B monomers is higher than 10-20\% of the total monomer yield, this would indicate that vinyl ethers are produced in the thermally-treated lignin samples.

\section{RESULTS AND DISCUSSION}

The cleavage of $\beta-\mathrm{O}-4$ linkages and enrichment in condensed bonds are the common features of many lignin degradation pathways (Westermark et al., 1997) (Brezny et al., 1984). In addition, some degradative processes such as kraft pulping (Gellerstedt et al., 1984) or pine wood thermal treatment (Vallet et al., 2001) may induce the loss of the $\gamma$ hydroxymethyl groups of lignin side-chains in the form of formaldehyde, leading to the formation of resistant vinyl ether structures. The formadehylde liberated by this reverse aldol condensation reaction may promote the recondensation of lignin aromatic rings through hydroxymethylation followed by the formation of diphenylmethane structures (Chiang and Funaoka, 1988; Gellerstedt et al., 2004). The effect of the thermal treatment on the Klason lignin content of spruce and beech wood is reported in Table II. As the amount of acido-soluble lignin was found to be low (less than $0.5 \%$ of the extractfree spruce wood and about $1 \%$ of the extract-free beech samples), this acido-soluble lignin fraction will not be considered further.

The level of Klason lignin in the extract-free samples increased with the severity of the thermal treatment, reaching very high values in the samples treated for $8 \mathrm{~h}$ at $280^{\circ} \mathrm{C}$ (close to $91 \%$ for spruce and close to $77 \%$ for beech). This result suggests that the cell wall polysaccharides were selectively eliminated in agreement with published data (Fengel and Wegner, 1989). However, for the harsher treatment, we cannot exclude the possibility that the lignin content is overestimated by the Klason method if such treatment induces some recondensation reactions between polysaccharides (or between polysaccharide degradation products) and lignins.

With this caveat in mind, we can conclude that the mildest treatment, i.e. $1 \mathrm{~h}$ at $220^{\circ} \mathrm{C}$, has little effect on the Klason 


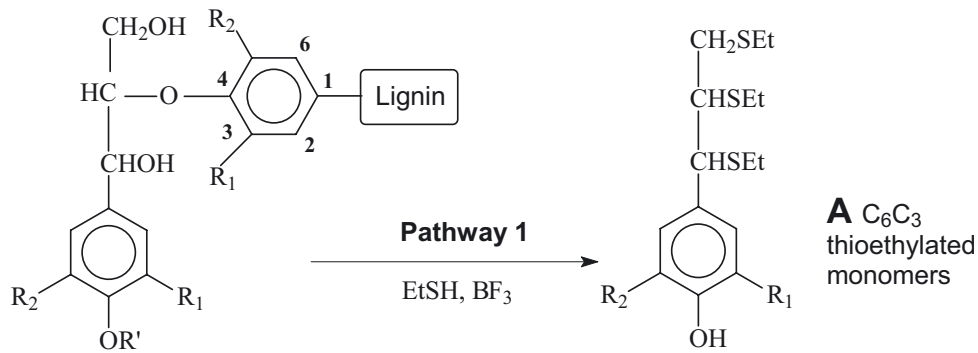

$$
\begin{aligned}
& H \text { unit : } R_{1}=R_{2}=H \\
& G \text { unit: } R_{1}=O M e ; R_{2}=H \\
& S \text { unit : } R_{1}=R_{2}=O M e
\end{aligned}
$$<smiles>[R2]Oc1c([R])cc(/C=C\Oc2c([R])cc(CCC3CCCC3)cc2[R])cc1[R]</smiles>
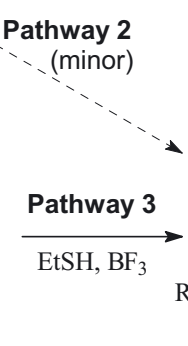<smiles>[R]c1cc(CC(CCC)CCC)cc([R])c1O</smiles>

B $\mathrm{C}_{6} \mathrm{C}_{2}$ thioethylated monomers

Figure 3. Lignin structural evaluation by thioacidolysis. Lignin $\mathrm{H}, \mathrm{G}$ or $\mathrm{S}_{6} \mathrm{C}_{3}$ units only involved in $\beta$-O-4 bonds essentially give rise to $\mathrm{C}_{6} \mathrm{C}_{3}$ thioethylated monomers (pathway 1 and monomers $\mathrm{A}$ ) and, to a much lower extent, to $\mathrm{C}_{6} \mathrm{C}_{2}$ thioethylated monomers (minor pathway 2 and monomers B). Lignin $\mathrm{H}, \mathrm{G}$ or $\mathrm{S}$ vinyl ether structures, originating from the loss of terminal hydroxymethyl groups during the chemical or physical treatment of wood lignins, essentially generate $\mathrm{C}_{6} \mathrm{C}_{2}$ thioethylated monomers (pathway 3 and monomers $\mathrm{B}$ ). The total yield and relative frequencies of the $\mathrm{H}, \mathrm{G}$ and $\mathrm{S}_{6} \mathrm{C}_{3}$ and $\mathrm{C}_{6} \mathrm{C}_{2}$ thioacidolysis monomers reflect the amount and composition of the parent lignin structures.

Table II. Lignin contents (\% weight) of the extract-free control and thermally-treated spruce and beech wood samples. Mean values and standard errors between duplicate analyses. The relative increase, as

\begin{tabular}{|c|c|c|c|c|}
\hline Spruce & & & & \\
\hline Control & Duration & $220^{\circ} \mathrm{C}$ & $250^{\circ} \mathrm{C}$ & $280^{\circ} \mathrm{C}$ \\
\hline \multirow{2}{*}{$\begin{array}{l}27.11 \pm 0.07 \\
(100)\end{array}$} & $1 \mathrm{~h}$ & $\begin{array}{c}28.76 \pm 0.15 \\
(106)\end{array}$ & $\begin{array}{c}33.33 \pm 0.43 \\
(123)\end{array}$ & $\begin{array}{c}46.28 \pm 0.16 \\
(171)\end{array}$ \\
\hline & $8 \mathrm{~h}$ & $\begin{array}{c}35.63 \pm 1.03 \\
(131)\end{array}$ & $\begin{array}{c}64.06 \pm 0.26 \\
(236)\end{array}$ & $\begin{array}{c}90.75 \pm 0.03 \\
(335)\end{array}$ \\
\hline \multicolumn{5}{|l|}{ Beech } \\
\hline Control & Duration & $220^{\circ} \mathrm{C}$ & $250^{\circ} \mathrm{C}$ & $280^{\circ} \mathrm{C}$ \\
\hline \multirow{2}{*}{$\begin{array}{l}22.73 \pm 0.04 \\
(100)\end{array}$} & $1 \mathrm{~h}$ & $\begin{array}{c}25.95 \pm 0.33 \\
(114)\end{array}$ & $\begin{array}{c}36.03 \pm 0.07 \\
(159)\end{array}$ & $\begin{array}{c}44.60 \pm 0.38 \\
(196)\end{array}$ \\
\hline & $8 \mathrm{~h}$ & $\begin{array}{c}34.46 \pm 0.09 \\
(151)\end{array}$ & $\begin{array}{c}59.27 \pm 0.09 \\
(261) \\
\end{array}$ & $\begin{array}{c}77.45 \pm 0.21 \\
(341) \\
\end{array}$ \\
\hline
\end{tabular}
compared to the control sample set at 100 , is indicated in brackets.

lignin content of the sample whereas $8 \mathrm{~h}$ at the same temperature substantially increases this Klason lignin content (by $30 \%$ in spruce and $50 \%$ in beech). Such an increase can be related to the selective loss of hemicellulose components, in agreement with a recent study on the thermal treatment of beech wood. The harshest treatment $\left(8 \mathrm{~h}\right.$ at $\left.280{ }^{\circ} \mathrm{C}\right)$ multiplies the Klason lignin content by almost 3.4 in both samples.

In agreement with previous studies (Lindberg et al., 2003; Vallet et al., 2001; Windeisen and Wegener, 2008), the results presented in Table III demonstrate that the extent to which spruce lignin $\beta-O-4$ structures are targeted in the thermal treat- ment is directly correlated to the treatment severity. Even the mildest treatment $\left(1 \mathrm{~h}\right.$ at $\left.220{ }^{\circ} \mathrm{C}\right)$, which did not substantially change the Klason lignin content (Tab. III), markedly decreased the yield in thioacidolyis monomers. In other words, although the lignin content is not affected by this moderate treatment, the results from thioacidolysis show that it substantially modifies lignin structure. After the severe treatment at $280{ }^{\circ} \mathrm{C}$, the $\mathrm{G}$ units only involved in $\beta \mathrm{O}-4$ bonds had almost entirely disappeared.

As seen in Table III, the relative importance $(\% \mathrm{~B} / \mathrm{A}+\mathrm{B})$ of the guaiacyl $\mathrm{C}_{6} \mathrm{C}_{2} \mathrm{G}$ monomers increases with treatment severity. This result suggests that the thermal treatment induces the formation of vinyl ether structures in spruce lignins. Consistent with the dramatic decrease in thioacidolysis yield, it is very likely that the formaldehyde liberated during the formation of these vinyl ethers participates in the formation of resistant interunit bonds in lignins, such as diphenylmethane type structures. During the thermal treatment, spruce lignins would be thus cross-linked by reactions similar to those occurring during the curing of formo-phenolic resins.

Beside the main $\mathrm{G}$ monomers, $\mathrm{H}$ monomers can be recovered from the thioacidolysis of the control and thermallytreated spruce samples (Tab. IV). These $\mathrm{H}$ monomers are detected in relatively small and constant proportions in most samples, which suggests that the condensation reactions affect the $\mathrm{G}$ and the $\mathrm{H}$ lignin units similarly.

In addition to $\mathrm{C}_{6} \mathrm{C}_{3}$ and $\mathrm{C}_{6} \mathrm{C}_{2}$ monomers, thioacidolysis releases some $\mathrm{C}_{6} \mathrm{C}_{1}$ compounds such as vanillic acid and vanillin (obtained in the form of its dithioketal derivative). 
Table III. Yields of lignin-derived thioacidolysis G and H monomers recovered from thermally-treated spruce wood samples and controls. Yields expressed in $\mu$ moles per gram of the Klason lignin content of the extract-free samples. Data are the mean values (standard errors) of duplicate analyses; Tr: trace amount; Nd: not detected.

\begin{tabular}{|c|c|c|c|c|c|c|c|}
\hline \multirow[t]{2}{*}{ Compound } & P1 & $\mathrm{P} 2$ & $\mathrm{P} 3$ & $\mathrm{P} 4$ & $\overline{\mathrm{P} 5}$ & P6 & P7 \\
\hline & Spruce & $220^{\circ} \mathrm{C}$ & $250{ }^{\circ} \mathrm{C}$ & $280{ }^{\circ} \mathrm{C}$ & $220^{\circ} \mathrm{C}$ & $250^{\circ} \mathrm{C}$ & $280{ }^{\circ} \mathrm{C}$ \\
\hline $\mathrm{A}$ & 1418 & 864 & 406 & 25.1 & 259 & 4.2 & 0.098 \\
\hline $\mathrm{B}$ & 110 & 133 & 115 & 35.5 & 79.7 & 5.0 & 1.02 \\
\hline $\mathrm{G}-\mathrm{CH}_{2}-\mathrm{CH}(\mathrm{SEt})_{2}$ & $(15)$ & (3) & (1) & (1.6) & $(0.3)$ & $(0.4)$ & $(0.09)$ \\
\hline$(\mathrm{A}+\mathrm{B})$ & 1528 & 997 & 521 & 61 & 339 & 9.2 & 1.11 \\
\hline$\% \mathrm{~B} /(\mathrm{A}+\mathrm{B})$ & $(0.5)$ & $(0.6)$ & $(0.3)$ & $(0.2)$ & $(0.2)$ & $(2.5)$ & $(0.5)$ \\
\hline \multirow[t]{2}{*}{ H-CHSEt-CHSEt-CH ${ }_{2}$ SEt } & 7.3 & 5.9 & 1.2 & $\operatorname{Tr}$ & 2.4 & $\mathrm{Nd}$ & $\mathrm{Nd}$ \\
\hline & $(0.8)$ & $(0.1)$ & $(0.1)$ & & $(0.1)$ & & \\
\hline Vanillic acid & 12.7 & 14.5 & 15.4 & 4.7 & 32.2 & 9.1 & 0.8 \\
\hline $\mathrm{G}-\mathrm{COOH}$ & (0.6) & $(0.3)$ & $(0.4)$ & $0.1)$ & $(0.1)$ & (0.3) & $(0.0)$ \\
\hline
\end{tabular}

Table IV. Yields of lignin-derived thioacidolysis $\mathrm{G}$ and $\mathrm{S}$ monomers $\left(\mathrm{C}_{6} \mathrm{C}_{3}+\mathrm{C}_{6} \mathrm{C}_{2}\right)$ recovered from thermally-treated beech wood samples and controls. Yields expressed in $\mu$ moles per gram of the Klason lignin content of the extract-free samples. Data are the mean values (standard errors) of duplicate analyses.

\begin{tabular}{|c|c|c|c|c|c|c|}
\hline Compound & $\begin{array}{c}\text { P8 } \\
\text { Beech } \\
\text { control }\end{array}$ & $\begin{array}{c}\mathrm{P} 9 \\
220^{\circ} \mathrm{C} \\
1 \mathrm{~h}\end{array}$ & $\begin{array}{c}\mathrm{P} 10 \\
250{ }^{\circ} \mathrm{C} \\
1 \mathrm{~h}\end{array}$ & $\begin{array}{c}\mathrm{P} 11 \\
280^{\circ} \mathrm{C} \\
1 \mathrm{~h}\end{array}$ & $\begin{array}{c}\mathrm{P} 12 \\
220^{\circ} \mathrm{C} \\
8 \mathrm{~h}\end{array}$ & $\begin{array}{c}\mathrm{P} 13 \\
250{ }^{\circ} \mathrm{C} \\
8 \mathrm{~h}\end{array}$ \\
\hline $\mathrm{A}_{\mathrm{G}} \mathrm{G}-\mathrm{CHSEt}-\mathrm{CHSEt}-\mathrm{CH}_{2} \mathrm{SEt}$ & $\begin{array}{l}813 \\
(30)\end{array}$ & $\begin{array}{c}386 \\
(8)\end{array}$ & $\begin{array}{l}43 \\
(5)\end{array}$ & $\begin{array}{c}1.5 \\
(0.2)\end{array}$ & $\begin{array}{l}51 \\
(6)\end{array}$ & $\begin{array}{c}1.6 \\
(0.1)\end{array}$ \\
\hline $\mathrm{A}_{\mathrm{S}} \mathrm{S}$-CHSEt-CHSEt-CH${ }_{2} \mathrm{SEt}$ & $1918(59)$ & $\begin{array}{c}998 \\
(4)\end{array}$ & $\begin{array}{l}129 \\
(10)\end{array}$ & $\begin{array}{c}2.4 \\
(0.2)\end{array}$ & $\begin{array}{c}134 \\
(9)\end{array}$ & $\begin{array}{c}2.4 \\
(0.0)\end{array}$ \\
\hline $\mathrm{B}_{\mathrm{G}} \mathrm{G}-\mathrm{CH}_{2}-\mathrm{CH}(\mathrm{SEt})_{2}$ & $\begin{array}{l}39 \\
(2)\end{array}$ & $\begin{array}{l}63 \\
\text { (3) }\end{array}$ & $\begin{array}{l}31 \\
(2)\end{array}$ & $\begin{array}{c}7.1 \\
(0.1)\end{array}$ & $\begin{array}{l}24 \\
(2)\end{array}$ & $\begin{array}{c}2.1 \\
(0.0)\end{array}$ \\
\hline $\mathrm{B}_{\mathrm{S}} \mathrm{S}-\mathrm{CH}_{2}-\mathrm{CH}(\mathrm{SEt})_{2}$ & $\begin{array}{l}49 \\
\text { (3) }\end{array}$ & $\begin{array}{c}121 \\
(2)\end{array}$ & $\begin{array}{l}57 \\
(4)\end{array}$ & $\begin{array}{c}8.7 \\
(0.2)\end{array}$ & $\begin{array}{l}40 \\
\text { (2) }\end{array}$ & $\begin{array}{c}2.5 \\
(0.0)\end{array}$ \\
\hline$(\mathrm{A}+\mathrm{B})$ & $2819(94)$ & $\begin{array}{c}1568 \\
(17)\end{array}$ & $\begin{array}{l}260 \\
(21)\end{array}$ & $\begin{array}{l}19.7 \\
(0.7)\end{array}$ & $\begin{array}{l}249 \\
(19)\end{array}$ & $\begin{array}{c}8.6 \\
(0.1)\end{array}$ \\
\hline$\% \mathrm{~B} /(\mathrm{A}+\mathrm{B})$ & 3 & 12 & 33 & 80 & 26 & 53 \\
\hline $\mathrm{S} / \mathrm{G}$ & 2.31 & 2.49 & 2.49 & 1.30 & 2.32 & 1.32 \\
\hline
\end{tabular}

Their recovery from the extract-free control sample demonstrates that vanillin and vanillic acid end-groups pre-exist in this sample as cell wall-linked structures. However, their relative proportion substantially increases with treatment severity (Tab. III). This result suggests that additional vanillic acid and vanillin end-groups are formed during the treatment, probably through the oxidative cleavage of the lignin side-chains, even though the treatment is conducted in an inert nitrogen atmosphere

Beech lignins are mostly made up of $\mathrm{G}$ units and $\mathrm{S}$ units bound by $\beta-\mathrm{O}-4$ linkages and/or condensed linkages. The raw thioacidolysis data (Tab. IV) show that beech lignins are dramatically altered by the thermal treatment, to an extent that seems to exceed the structural alterations observed for spruce samples. The decreased yield of the main $\mathrm{C}_{6} \mathrm{C}_{3}$ thioacidolysis monomers reflects the progressive disappearance of lignin units only involved in $\beta \mathrm{O}-4$ bonds and the formation of con- densed linkages in proportions related to treatment severity. The sample heated for $8 \mathrm{~h}$ at $280{ }^{\circ} \mathrm{C}$ produces only trace amounts of thioacidolysis monomers, as can be seem on the chromatogram reconstructed on specific ions. The relative importance of $\mathrm{C}_{6} \mathrm{C}_{2}$ thioacidolysis monomers released by thermally-treated beech samples dramatically increases with the treatment severity, which traduces the formation of vinyl ether structures together with the release of formaldehyde. According to published data (Funaoka et al., 1990) and consistent with the massive concomitant formation of vinyl ethers and of formaldehyde, 40 to $75 \%$ of the non-condensed units of native lignins would be converted into diphenylmethane type structures above $220{ }^{\circ} \mathrm{C}$. The study of the minor $\mathrm{C}_{6} \mathrm{C}_{1}$ thioacidolysis compounds, namely vanillic acid, syringic acid, vanillin dithioketal and syringaldehyde dityhioketal, revealed that their relative importance was increased by the thermal treatment (data not shown). This result suggests that thermal treatment 


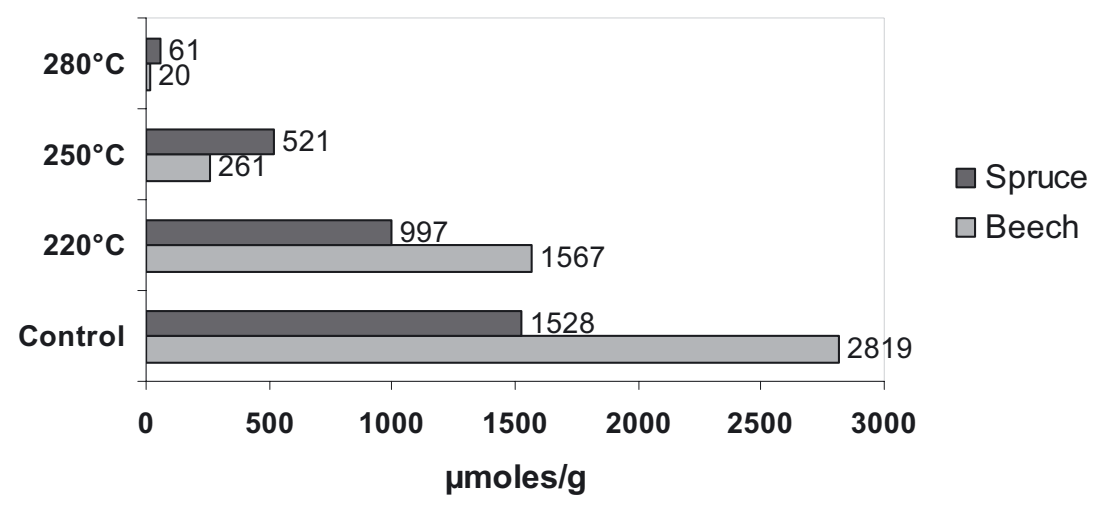

Figure 4. Yield of the main monomers $A_{G}$ (spruce) and $\left(A_{G}+A_{S}\right)$ (beech) from thioacidolysis of spruce and beech wood thermally-treated for 1 hour at various temperatures.



Figure 5. Relative importance (\% molar) of $\mathrm{C}_{6} \mathrm{C}_{2}$ monomers from thioacidolysis of spruce and beech wood thermally-treated for 1 hour at various temperatures.

induces some oxidative cleavage of lignin side-chains in beech lignins, similar to the case in spruce lignins and despite the inert atmosphere.

The residual $\beta-\mathrm{O}-4$ structures in the severely degraded lignins $\left(280{ }^{\circ} \mathrm{C} 1 \mathrm{~h}\right.$ and $250{ }^{\circ} \mathrm{C} 8 \mathrm{~h}$ ) display a lower $\mathrm{S} / \mathrm{G}$ ratio than the $\beta-\mathrm{O}-4$ structures of the native lignins (Tab. V), suggesting that $\beta-\mathrm{O}-4$ linked $\mathrm{G}$ units are more resistant than their $\mathrm{S}$ homologues. This result also explains the difference in the viscoelastic behaviour (thermal activation and thermal degradation) of softwoods and hardwoods (Placet et al., 2008). The distinct kinetics of the thermal degradation of $\mathrm{S}$ and $\mathrm{G}$ units is confirmed by comparing the data for beech and spruce samples. As shown in Figure 4, the thermally-induced thioacidolysis yield decreases more regularly for the spruce lignin samples, constituted only of $\mathrm{G}$ units, than for those of beech lignin, constituted of $\mathrm{G}$ and $\mathrm{S}$ units. This result further confirms that hardwood lignins are more susceptible to thermal treatment than softwood lignins. By contrast, the formation of vinyl ether structures, which is monitored by the relative amounts of the $\mathrm{C}_{6} \mathrm{C}_{2}$ thioacidolysis monomers (Fig. 5), seems to be induced to the same extent in the spruce and beech samples.

\section{CONCLUSION}

The phenolic character of lignins endows them with antioxidant capacities, which enable them to deactivate radicals of low stability formed during the thermal degradation of hemicelluloses (Nuopponen, 2005). Such scavenging of radicals would occur through reactions of radical transfer, resulting in the formation of stable phenoxy radicals which have been revealed by electron paramagnetic resonance spectroscopy (EPR) (Ahhaji et al., 2003). Thus, the relative increase in the concentration of phenoxy radicals caused by thermal treatment result from two processes :

- the direct thermal degradation of phenolic compounds;

- the degradation of hemicelluloses with the formation of radical species that react with the phenolic compounds of wood.

In both cases, there would be a temperature threshold between 210 and 235 above which the stationary concentration of phenoxy radicals is little altered by treatment temperature. This confirms the importance of a critical temperature, situated around $230{ }^{\circ} \mathrm{C}$ (Nuopponen, 2005; Stamm, 2006).

The present results confirm that spruce and beech lignins are highly reactive with respect to the employed thermal treatment .(Nguila Inari et al., 2007). Assuming that the Klason method for measuring lignin content is applicable to this type of sample, this standard test reveals that these polymers are more resistant than polysaccharides to prolonged treatment at high temperatures $\left(220,250\right.$ and $\left.280{ }^{\circ} \mathrm{C}\right)$ in an inert atmosphere. Precise monitoring of weight loss during the thermal 
treatment would make it possible to determine whether a part of the lignin is degraded into volatile compounds in the more extreme treatments. The study of lignin structure using thioacidolysis shows intense structural transformations with the following degradation reactions:

- The cleavage of lignin $\beta-\mathrm{O}-4$ bonds.

- Severe recondensation reactions, which leads to considerable enrichment of resistant interunit bonds in the thermally-treated lignins.

- The formation of vinyl ether structures through the loss of the terminal hydroxymethyl groups from lignin sidechains; the liberated formaldehyde then participates in crosslinking the polymer according to similar mechanisms to those of heat-hardened formo-phenolic resins.

- To a lesser extent, the oxidative cleavage of the $\mathrm{C} \alpha-\mathrm{C} \beta$ benzylic bonds with the formation of benzoic acid and benzoic aldehyde end-groups in lignins.

Acknowledgements: We sincerely thank F. Legée (AgroParistech, UMR CB) and L. Cézard (INRA, UMR CB) for running the lignin analyses.

\section{REFERENCES}

Ahhaji A., El Bakali I., George B., and Merlin A., 2003. Analyse par spectroscopie de résonance paramagnétique électronique (RPE) de bois traités thermiquement exposés à un rayonnement de type solaire. Annales Gis-bois (Eds.), Nancy, France.

Arias B., Pevida C., Fermoso J., Plaza M.G., Rubier F., and Pisa J.J., 2008. Influence of torrefaction on the grindability and reactivity of woody biomass. Fuel Process. Technol. 89: 169-175.

Baumberger S., Dole P., and Lapierre C., 2002. Using transgenic poplars to elucidate the relationship between the structure and the thermal properties of lignins. J. Agric. Food Chem. 50: 2450-2453.

Bilbao R., Mastral J.F., Aldea M.E., and Ceamanosa J., 1997. The influence of the percentage of oxygen in the atmosphere on the thermal decomposition of lignocellulosic materials. J. Anal. Appl. Pyrolysis 42: 189-202.

Blazek J., Buryan P., Grouset D., Soudais Y., and Tekac V., 2001. Study of the thermical degradation of lignin in the inert atmosphere. Entropie 235/236: 6-11

Boonstra M., van Acker J., Tjeerdsma B., and Kegel E.V., 2007. Strength properties of thermally modified softwoods and its relation to polymeric structural wood constituents. Ann. For. Sci. 64: 679-690.

Borrega M. and Kärenlampi1 P.P., 2007. Mechanical behavior of heattreated spruce (Picea abies) wood at constant moisture content and ambient humidity. Holz Roh Werkst. 66: 63-69.

Bourgois J., Bartholin M.C., and Guyonnet R., 1989. Thermal treatment of wood: analysis of the obtained product. Wood Sci. Technol. 23: 303-310.

Branca C. and Di Blasi C., 2003. Kinetics of the isothermal degradation of wood in the temperature range 528-708K. J. Anal. Appl. Pyrolysis 67: 207-219.

Brezny R., Surina L., and Kosik M., 1984. Low temperature thermolysis of lignins. II. Thermofractography and thermal analysis of $\beta-\mathrm{O}-4$ model compounds. Holzforschung 38: 19-24.

Chakar F.S. and Ragauskas A.J., 2004. Review of current and future softwood kraft lignin process chemistry. Ind. Crop. Prod. 20: 131-141.

Chiang V.L. and Funaoka M., 1988. The formation and quantity of diphenylmethane type structures in residual lignin during kraft delignification of Douglas-fir. Holzforschung 42: 385-391.
Dence C.W., 1992.The determination of lignin. In: Dence C.W. (Ed.), Method in lignin chemistry, Springer-Verlag, Berlin, Heiderberg, New York, pp. 33-61.

Fengel D. and Wegner G., 1989. Wood - Chemistry, ultrastructure, reactions. Walter de Gruyter, Berlin, New-York, 344 p.

Funaoka M., Kako T., and Abe L., 1990. Condensation of lignin during heating of wood. Wood Sci. Technol. 24: 277-288.

Gellerstedt G., Lindfors E.L., Lapierre C., and Monties B., 1984. Structural changes in lignin during kraft cooking. Part 2. Characterization by acidolysis. Svensk Papperstidning: 61-67.

Gellerstedt G., Majtnerova A., and Zhang L., 2004. Towards a new concept of lignin condensation in kraft pulping. Initial results. C.R. Biol. 327: 817-826.

Kocaefe D., Chaudhry B., Poncsak S., Bouazara M., and Pichette A., 2006. Thermogravimetric study of high temperature treatment of aspen: effect of treatment parameters on weight loss and mechanical properties. J. Mater. Sci. 42: 854-866.

Kotilainen R.A., Toivanen T.J., and Alen R.J., 2000. FTIR monitoring of chemical changes in softwood during heating. J. Wood Chem. Technol. 20: 307-320.

Lindberg J.J., Levon K., and Kuusela T., 2003. Modification of lignin. Acta Polymer. 39: 47-50.

Mouras S., Girard P., Rousset P., Permadi P., Dirol D., and Labat G., 2002. Propriétés physiques de bois peu durables soumis à un traitement de pyrolyse ménagée. Ann. For. Sci. 59: 317-326.

Nguila Inari G., Petrissans M., and Gerardin P., 2007. Chemical reactivity of heat-treated wood. Wood Sci. Technol. 41: 157-168.

Nuopponen M., Vuorinen T., Jämsä S., and Viitaniemi P., 2005. Thermal modifications in softwood studied by FTIR and UV resonance Raman spectroscopies. J. Wood Chem. 24: 13-26.

Placet V., Passard J., and Perré P., 2008. Viscoelastic properties of wood across the grain measured under water-saturated conditions up to $135{ }^{\circ} \mathrm{C}$ : evidence of thermal degradation. J. Mater. Sci. 43: 32103217

Rapp A.O., 2001. Review on heat treatments of wood. COST Action E22 - Environmental of wood protection, Antibes, France.

Rolando C., Montiés B., and Lapierre C., 1992. Thioacidolysis. In: Lin S.Y. and Dence C.W. (Eds.), Methods in lignin chemistry, Springerverlag, Berlin, pp. 334-349.

Rousset P., Turner I., Donnot A., and Perré P., 2006. Choix d'un modèle de pyrolyse ménagée du bois à l'échelle de la microparticule en vue de la modélisation macroscopique. Ann. For. Sci. 63: 213-229.

Scheffer T.C. and Eslyn W.E., 1961. Effect of heat on the decay resitance of wood. For. Prod. J. 46: 485-490.

Stamm A.J., 1946. Heat-stabilized wood. Industrial and engineering chemistry. 38: 630-634.

Tjeerdsma B., Boonstra M., Pizzi A., Tekeley P., and Militz H., 1998. Characterisation of thermally modified wood: molecular reasons for wood performence improvement. Holz Roh Werkst. 56: 149-153.

Vallet C., Alvez E., Mila I., Pollet B., Weiland J., Guyonnet R., and Lapierre C., 2001. Rectification du pin maritime : structure des lignines et propriétés du bois. In: ar.bo.lor. (Ed.), Les Cahiers scientifiques du bois, Nancy,

Westermark U., Samulesson B., and Lundquist K., 1997. Homolytic cleavage of the $\beta$-ether bond in phenolic $\beta$-O- 4 ether structures ant its significance in high-yield pulping and lignin analysis. Nord. Pap. Res. J. 12: 150-154.

Windeisen E., Strobel C., and Wegener G., 2007. Chemical changes during the production of thermo-treated beech wood. Wood Sci. Technol. 41: 523-536.

Windeisen E. and Wegener G., 2008. Behaviour of lignin during thermal treatments of wood. Ind. Crop. Prod. 27: 157-162.

Yildiz S., Gezer E., and Yildiz U.C., 2006. Mechanical and chemical behavior of spruce wood modified by heat. Build. Environ. 41: 17621766. 